\title{
SOCIAL ENTREPRENEURSHIP: CHALLENGE NOT ONLY FOR DEVELOPING COUNTRIES BUT ALSO FOR THE EU
}

\author{
Marek Jetmar, College of Regional Development, jetmar.marek@seznam.cz
}

Social enterprises (businesses) represent an emerging sector not only in developing countries but also in the EU. The deepening of social problems associated with high unemployment of graduates, persons at age over 50 years and other vulnerable groups in the labour market brings new impulses for designing public policy and development of cooperation between the different actors (role of NGOs, financial intermediaries, local authorities, etc). The paper focuses on the environment analysis - regulatory approaches, forms and types of support, quality of financial services at European level and states and regions from Western, Central and Northern Europe, involved in the learning Network for Better Future of Social Economy. We can say, the status of the social economy and opportunities are different in each country as a result of reflection of value orientation of society, the quality of the environment. However, it is possible to identify common problems and typical ways to support social economy. It means to overcome lack of co-operation between financial sector, NGOs and public sector in providing funding for social enterprises, to provide mix of private and public funds in order to solve problem connected with funds insufficiency. It is necessary to set up integrated support schemes allowing the use of various types of financial instruments (grant mechanisms, loans using financial engineering instruments). It is necessary to couple the investment in social enterprises with investment in human capital.

JEL Classification Numbers: I38, R58, O15, DOI: 10.12955/cbup.2013.13

Key words: social economy, social business and entrepreneurship

\section{Introduction}

Social enterprises represent an emerging sector not only in developing countries but also in the EU. They are comprised of undertakings whose primary objective is to achieve social impacts rather than generate profits for shareholders. To achieve these impacts, social enterprises seek to build on business techniques - including business finance. The sector is characterised by a rapid growth. As Terjesen, Lepoutre, Justo \& Bosma (2011) write in the Global Entrepreneurship Monitor 2009 report, between $3 \%$ and $7.5 \%$ of the workforce in selected EU Member States were employed in various forms of social businesses.

The social mission of social enterprises is connected with a strong focus on sustainable or inclusive development, and on tackling social challenges across EU societies: It means that investment in social enterprises is likely to have a greater positive social impact than investment in SMEs in general. As Bosma \& Levie (2010) write: "Social entrepreneurs differ widely in the type of organizations launched and the kind of social or environmental problem they try to solve. Social enterprises identified in this 
report span across a wide array of areas such as education, health, culture, economic development and the environment. While sector participation does not vary much by country, there are differences in social issue focus among the three country groups by economic development. Social entrepreneurs in factor-driven economies tend to focus on more elementary issues and pressing needs such as basic health care provision, access to water and sanitation or agricultural activities in rural areas. In innovation-driven economies, individuals are particularly active in launching culture-related organizations, providing services for disabled people, focusing on waste recycling and nature protection or offering open-source activities such as online social networking."

The sustainable growth of the EU's social enterprise sector depends on drawing on a wide range of investment and financing sources. The EU level has just taken some initiatives and others are in the process.

\section{Social entrepreneurship, social business}

Social entrepreneurship means identifying or recognizing a social problem and using entrepreneurial principles to organize, create, and manage a social venture to achieve a desired social change. Business entrepreneurs typically measure performance in profit and return, but social entrepreneurs also take into account a positive return to society. Social entrepreneurship typically furthers broad social, cultural, and environmental goals and it is commonly associated with the voluntary and not-forprofit sectors. Profit can at times also be a consideration for certain companies or other enterprises.

One well-known contemporary social entrepreneur is Muhammad Yunus, founder and manager of Grameen Bank and many social venture businesses, who was awarded a Nobel Peace Prize in 2006. The work of Yunus (i. e. Yunus, M. (2010)) and Grameen echoes a theme among social entrepreneurs that emphasizes the enormous synergies and benefits when business principles are unified with social ventures. In some countries - including Bangladesh - social entrepreneurs have filled the spaces left by a relatively small state. In other countries - particularly in Europe and South America - they have tended to work more closely with public organizations at both the national and local level.

European Commission has defined social enterprise (COM (2011) 682, 25.10.2011) as any enterprise, whatever its legal status,

1. As the achievement of measurable, positive social impacts as a primary objective, where the undertaking:

- provides services or goods to vulnerable, marginalised, disadvantaged or excluded persons, and/or

- provides goods or services through a method of production, which embodies its social objective.

2. As how they use their profits first and foremost to achieve its primary objectives instead of distributing profits, and has in place predefined procedures and rules for any circumstances in which profits are distributed to shareholders and owners which ensure that any such distribution of profits does not undermine its primary objectives, and

3. How it is managed in an accountable and transparent way, in particular by involving workers, customers and/or stakeholders affected by its business activities.

\section{The EU activities}

The European Commission states in its Social Business Initiative (COM (2011) 682, 25.10.2011), (European Parliament, November 20, 2012) that the funding system for social enterprises is 
underdeveloped compared with that used by other businesses. Different financial tools and an appropriate regulatory framework are necessary in order to establish equal access to capital for social enterprises. For example, the Commission has proposed a microcredit initiative for social enterprises as part of the Programme for Social Change and Innovation (COM (2011) 609, 6.10.2011), which is to start in 2014. This programme includes a funding instrument for the start-up, development and expansion of social enterprises. The aim is to provide approximately $€ 450$ million in microloans as well as approximately $€ 100$ million for direct support to social enterprise development. The aim of new European Social Entrepreneurship Funds (COM (2011) 862, 7.12.2011) is to facilitate access to the financial markets for social enterprises by harmonising rules for investment funds.

Even if all these initiatives are welcome in order to improve the supply of appropriate capital for social enterprises, more actions are needed. These initiatives need to be regarded as the first step towards tailored financial instruments that still need to be explored.

When designing an appropriate financial framework, it is also important to look at existing investment instruments specifically developed and adapted for social enterprises. These include social investment funds, cooperative banks, ethical and social banks, commercial banks with social programmes, innovative instruments such as British "social impact bonds" and favourable tax-funded solutions. Such instruments could be used as part of a hybrid capital approach, which is often seen as the most appropriate model for financing social enterprises.

The ESF represents unique opportunity that allows solving most problems of social enterprises. The ESF is able to support most of the measures linked to the development of SE. Its resources can be used to co-finance the vast majority of the identified needs such as:

- to improve access to capital (investment, working) - loans, equity,

- to encourage local financial intermediaries - increase of resources,

- to strengthen the capacity of financial intermediaries - their ability to work with SE,

- to strengthen the capacity of social enterprises - their ability to access finance,

- to improve environment through informing relevant stakeholders.

\section{Social economy in some countries of the learning Network for Better Future of Social Economy}

The issue of social entrepreneurship in many countries and regions is at the heart of the entire society (Diesis, 2010; Sach (Ed.), 2010; Jetmar, 2012a). It represents a part of extensive societal debates on the role of social entrepreneurship in solving societal and social problems and the degree of involvement of the public sector (state, regions and municipalities) in resolving them. However, achieved level of development of social economy and social business is very different.

The quality of the business environment for social enterprises is determined by adjusting the regulatory functions for small and medium-sized enterprises, preferential measures aimed at reinforcement of social economy and development of social enterprises. Setting up the quality of the environment is related to the functioning of public institutions as guarantors of the system, type and intensity of regulation, appreciation of the value added of social entrepreneurship by society, awareness of stakeholders about the benefits of social entrepreneurship. The understanding of social economy and social entrepreneurship in participating countries and regions is varied, nevertheless it is 
possible to determine common features as achieving social objectives (society, community), and social enterprises are independent legal entities. The differences are in the regulation of social entrepreneurship (special legal form vs. traditional profit or non-profit legal forms), and in attitudes how to distribute profit (total absence of any profit-making features vs. rules of profit sharing between shareholders and the future company activities - e.g. investment activities).

\section{The Czech Republic (CR)}

The Czech concept of social enterprises is broad with great emphasis on economic and social objectives (business and social missions) that should be in balance. Most of the existing social enterprises in the $\mathrm{CR}$ are focused on the employment of disadvantaged people (the so-called integration social enterprises). Many of them have the status of sheltered workshops that employ people with disabilities. In addition to the above mentioned integration social enterprises in the Czech Republic there are also social enterprises that provide charitable services in the field of social inclusion and community development activities including the environmentally-oriented (green) enterprises or enterprises selling fair trade products. Nongovernmental organizations run a social business (or would like to begin with) in their complementary activities in order to use profits to fund their core charitable activities / mission.

Most of the existing social enterprises engage persons with disabilities, which is influenced by tradition and relatively clearly defined subsidies from employment services and status of this type of disadvantage compared to other types. But we can also find businesses that employ Roma, young people leaving orphanages, homeless people, people with drug history, etc. Social enterprises in the CR take different legal forms - it depends on specific conditions, the type of services / products or access to the founders.

There is no legal definition of social enterprises, though some factual and technical requirements have to be fulfilled while asking for start-up grants or development phase (scaling-up) grants from the ESF and the ERDF global grants (e.g. at least $40 \%$ of disadvantaged employees, over $51 \%$ of profit to be reinvested, principles of local development, empowerment of employees). The eligible applicants are enterprises or self-employed individuals. These forms of business legal entities are eligible: limited liability company, joint - stock company, limited partnership, cooperative, public company and business legal entity operating under the authority pursuant to special legislation. The applicants may also be some nongovernmental organizations - non-profit societies and registered religious legal persons.

Social enterprises in the Czech Republic are still nascent and social economy sector is weak. The majority of society does not share the values associated with social entrepreneurship, although the situation of disadvantaged people and the overall social climate deteriorates. So far there is no broader support for concept of social economy amongst policy makers at national and regional level. It will be necessary to strengthen awareness of the different actors about the benefits of social enterprises. Subsidies are provided only for disabled employees as a measure of the employment policy. The financial sector provides products (loans) for social enterprises in small scale as pilot initiative in the frame of CSR activities. The activities of NGOs in social entrepreneurship area are still weak although improvements can be observed (pilot projects on the formation of social enterprises). Support to social enterprises has pilot and innovative character and is essentially funded by grants from the ESF and the ERDF. 


\section{Poland}

In Poland social enterprises run a business focused on social objectives (spend profits for social purposes), i.e. social cooperatives, vocational rehabilitation facilities, mutual insurance companies, public benefit organizations, non-profit organizations, companies belonging to non-governmental organizations, labour cooperatives, mutual guarantee and loan funds (including microfinance institutions) and NGOs involved in economic activities. Their goal is to maximize social benefits, such as providing high quality public services, promoting local development and the restoration of dignity and economic independence of the socially excluded people.

In Poland there is a rapid growth of social enterprises from the bottom. This natural development responds to the significant social transformation of Polish society. Besides the massive support to the establishment and development of SMEs (available to social firms too) from the ERDF, there is also a number of measures directly focused on social enterprises, co-funded from the ESF. Emphasise is put on strengthening capacity of social enterprises and other actors in the territory. New ESF financial mechanism increasing availability of capital in the form of micro-credits for social entrepreneurs' start-ups is formed.

\section{Flanders, Belgium}

In Flanders, Belgium, social economy is highly developed and is significantly represented by enterprises focused on social and work inclusion. The regional government supports the development of social enterprises in every possible way. There is a sophisticated support system enabling to mobilize private resources. Public resources are then used as a lever to achieve the necessary effects. Various forms of partnership between the private and public sectors to support the social economy are well developed. Social entrepreneurship is constantly supported in various stages of development before starting a business, setting up businesses and in course of business. Attention is paid both to invest in to business (e.g. the purchase of equipment) such as human resource development (capacity building of social entrepreneurs and their employees).

Broad spectrum of social firms operates in Flanders. Most of them work as an integration firms (providing neighbourhood services, insertion companies, sheltered workshops, social workshops), they are recognized as support structures (start centres, financiers solidaires, advisory centre). There are also other entities with social goals as primary focus (co-operations - officially recognized).

Traditionally, social enterprises opt for the legal status of a cooperative or an association or a mutual benefit company or foundation. Now other forms are also possible as non-profit organizations, cooperative companies, accredited co-operatives (accredited by 9 National Council of Co-operatives if the articles of association include principles of democratic approach during general assembly with equal right to vote, limitation of dividend up to 6\%), European co-operatives, social purpose company, activity co-operatives (provide support to jobless people to activate them and test out their selfemployment activity) etc.

\section{The United Kingdom}

The UK Office of the Third Sector in the Cabinet Office defines social enterprise as "A social enterprise is a business with primarily social objectives whose surpluses are principally reinvested for that purpose in the business or in the community, rather than being driven by the need to maximise 
profit for shareholders and owners". The social enterprise in the UK has a long history, from the cooperative movement and mutual organisations to the long-standing trading activities of many charities. Development of social businesses became also an agenda of current government - Big Society Bank proposal (2011, May).

Social enterprises use a wide variety of legal forms. Community interest company (CIC) represents a legal form created specifically for social enterprises. It has a social objective that is "regulated" ensuring that the organisation cannot differ from its social mission and that its assets are protected. An industrial and provident society (IPS) is the usual form for cooperatives and community benefit societies, and is democratically driven by their members in order to ensure their involvement in the decisions of the business. Companies limited by guarantee or shares are the most common legal structure for businesses and often considered to be the most flexible, particularly companies limited by shares (they have a social mission written into their Memorandum and Articles of Association), entities with charitable status (Metz, B. (2011)). There are more than 62,000 social enterprises in the UK, employing over half a million people, with a combined turnover of more than GBP 27bn a year.

In the UK, the system of financing needs of social enterprises from private sources, non-governmental organizations and through direct involvement of citizens is very well developed. This reflects power of civil society sharing values of social economy in the population, but also the economic power of charities, foundations, endowment funds, which are able to support both the creation of social enterprises and support their projects. There are significant tax benefits and other measures promoting activity of social enterprises.

\section{Sweden}

In Sweden social enterprises do business aimed at integrating people into society and working life, and empowering employees. They re-invest their profits on their own or similar nature and are independent of the public sector. Some of the social enterprise activities are focused on the rehabilitation and labour-oriented services that are provided for remuneration from the public administration. In addition, social enterprises produce goods and/or services that are being sold in markets for individuals, companies or public sector.

The strategy and the objectives of the public activities are to create opportunities for more social enterprises to start and grow. High level of social cohesion at national and local level plays the crucial role in promoting the development of social enterprises. This is reflected in the promotion of ethical banking, which allows small savers to finance projects with social added value.

\section{Reflection of situation}

According to findings (Jetmar, 2012b), the situation of social business in participating countries and regions is different. It is associated with the 1) orientation value of society and the attitudes to marginalized groups of population, 2) role of the governments and public sector to address social inclusion and employment, 3) level of development of civil society, 4) political and institutional tradition. Although most values are now due to role of the ESF very similar, there exist significant differences regarding policy focus and range of financial instruments used and the accompanying mechanisms. However, it is possible to trace some common features of actors in social entrepreneurship and focus on their effective interaction. 
Funding options for social enterprises differ across countries and regions with regard to the quality of the business environment, the degree of development of the financial system, proportion of the social economy and the economic strength of the third sector.

The legal system and regulation usually do not create an immediate barrier to social business development. However, traditional legal forms of profit or non-profit oriented entities are matter of specific requirements relating to their status. On the one hand, (as to the business entities), there is an ideological contradiction with maximizing of profits (which is not the purpose of social entrepreneurship). On the other hand, a regular framework can impose restrictions on business behaviour of different forms of NGOs (foundations, charities).

Social entrepreneurs often face the problem with insufficient institutional support from the government in some countries. The reason is a lack of harmonized/unified employment policies, social inclusion and social entrepreneurship. It would be reasonable to align tools of active employment policy, social inclusion and promoting social entrepreneurship to encourage development of social entrepreneurship. It is appropriate to seek solutions that will harmonize support for social enterprise with development policy (local or regional development, community lead development). It is necessary to set up integrated support schemes combining traditional instruments of active employment policy - such as education, training, among other things aimed at strengthening business skills, ability to formulate a business plan and manage their own business.

Supporting framework should combine different types of incentives (such us discounts on social insurance, contributions to wage costs, social and health insurances) with grants or loans/equity for start-ups, preferential loans, micro-credits, guarantees for next development of social enterprises. One of the mechanisms that can be used in order to improve the business environment to social enterprises is the application of tax breaks and preferential accounting practices. Discounts on social insurance and contributions to employment of marginalized individuals are key components for competitiveness of social enterprises.

\section{Conclusion}

Social enterprises should be supported by different types of tools in order to influence their development, functioning in various stages of development. The idea is to create an environment that will enable effective and sustainable functioning of social enterprises (social and economic criteria). It is necessary to mobilize funds of the financial sector, third sector, citizens, etc. and seek ways of cooperation between private and public sector in order to increase availability of financial resources to social enterprises.

However, problem is the creation of comprehensive financial mechanisms (rules of combination resources affect the ability to create complex mechanisms - financial tools plus consulting services and education of stakeholders) and inadequate experience of some countries and regions with non-grant financial mechanisms. Uncertainties regarding the application of state aid may represent another problems - in many cases (because of doubt) only within by de minimis rule. This attitude results in addressing the consequences, but not the causes of problems.

Real availability of funds is only one element in the promotion of social economy and social entrepreneurship. Activities focused on increasing capacity and reinforcing of entrepreneurial skills of social entrepreneurs (before the launching and during their business) play crucial role. Increasing 
awareness of the importance of social economy for employment and social inclusion among local actors (including politicians) is also very important.

The main identified challenges regarding to implementation of support to social enterprises are:

1. Lack of co-operation between the financial sector, NGOs and the public sector in providing funding for social enterprises is necessary. From this perspective, local financial intermediaries need to understand the role and needs of social enterprises and recognise their financing as a business opportunity. Policy-makers and managing authorities should understand the constraints of financial intermediaries so as to strengthen their capacity to work with the social economy. The lack of capital or increased risk of lending can then be remedied by involving public resources - primarily in the form of guarantees - with a fair distribution of risk.

2. It is necessary to set up integrated support schemes allowing the use of various types of financial instruments and their combination (grant mechanisms, loans using financial engineering instruments). The aim is to make funds available for the different stages of development of social enterprises. Besides the initial capital investment it is also necessary to consider the availability of working capital to ensure the sustainability of social business.

3. It is efficient to couple the investment in social enterprises with investment in human capital. The ESF should be significantly focused on strengthening the capacity of social entrepreneurs and their employees, using already existing or developing new business support services for coaching and mentoring of social enterprises. Ensuring access to capital without the corresponding business services (advice, coaching, mentoring) only partly helps the development of social enterprises.

4. Finally, it would be appropriate to continue to strengthen the ability and capacity of Managing Authorities and other policy-makers to create integrated financial mechanisms co-funded by different funds (including the ESF or ERDF).

\section{References}

Bosma, N. \& Levie, J. (2010). Global Report 2009. Global Entrepreneurship Monitor, 2009. Babson Park, MA: Babson College. Retrieved February 20, 2013, from http://www.gemconsortium.org/docs/download/265

COM. (2011). 609 (final). Proposal for a Regulation of the European Parliament and of the Council on European Union Programme for Social Change and Innovation. Retrieved from http://eurlex.europa.eu/LexUriServ/LexUriServ.do?uri=CELEX:52011PC0609:EN:NOT

COM. (2011). 682 (final). Creating a favourable climate for social enterprises, key stakeholders in the social economy and innovation. Retrieved February 21, 2013, from http://eurlex.europa.eu/LexUriServ/LexUriServ.do?uri=COM:2011:0682:FIN:EN:PDF

COM. (2011). 862 (final). Proposal for a Regulation of the European Parliament and of the Council on European Social Entrepreneurship Funds. Retrieved Febrary 7, 2013, from http://ec.europa.eu/internal_market/investment/docs/social_investment/20111207proposal_en.pdf

DIESIS. (2010). Learning for change a better future of social economy, baseline study. Learning Network for Better Future of Social Economy (NBFSE). Retrieved February 20, 2013, from http://www.socialeconomy.pl/files/ekonomiaspoleczna.pl/public/_MRR_Better_Future/baseline.pdf 
European Parliament. (2012, November 20). Resolution on Social Business Initiative - Creating a favourable climate for social enterprises, key stakeholders in the social economy and innovation. Retrieved from http://www.europarl.europa.eu/sides/getDoc.do?pubRef=-//EP//TEXT+TA+P7-TA2012-0429+0+DOC+XML+V0//EN

Jetmar, M. (2012a). Overview of attitudes and financial instruments for social economy in NBFSE countries and case studies of selected practice of support. Learning Network for Better Future of Social Economy (NBFSE). Retrieved February 20, 2013, from http://www.socialeconomy.pl/files/ekonomiaspoleczna.pl/public/_MRR_Better_Future/BFSE_FI_Pro duct1-Overview_case_studies.pdf

Jetmar, M. (2012b). Recommendations for the implementation of financial instruments. Learning Network Better Future for Social Economy (NBFSE). Retrieved February 20, 2013, from http://www.socialeconomy.pl/files/ekonomiaspoleczna.pl/public/_MRR_Better_Future/Recommendati ons_for_implementation_FI_fin-fin1.pdf

Metz, B. (2011). The infrastructure of the social economy in the UK: A report for Nova Ekonomika. Retrieved February 20, 2013, from http://www.ceske-socialni-podnikani.cz/cz/ke-stazeni/569-studieinfrastruktury-socialni-ekonomiky-v-cr

Sach, K. (Ed.) (2010). The atlas of jobs creation good practices for social inclusion, ethical finance for an active, creative and solidarity-based Europe. Brussels, Belgium: FISE.

Terjesen, S., Lepoutre, J., Justo, R. \& Bosma, N. (2011). Global Entrepreneurship Monitor Report on Social Entrepreneurship, Executive summary. Global Entrepreneurship Research Association (GERA). Retrieved February 20, 2013, from www.gemconsortium.org/docs/download/376http://

UK government (2011, May). Big Society Bank proposal.

Retrieved February 20, 2013, from http://www.cabinetoffice.gov.uk/sites/default/files/resources/bigsociety-bank-outline-proposal.pdf

Yunus, M. (2010). Building Social Business: The New Kind of Capitalism that Serves Humanity's Most Pressing Needs. New York, NY: Public Affairs. 